\title{
Studies on the chemical constituents of leaves of Phyllanthus emblica (L.)
}

\author{
JAYA GUPTA, AMIT GUPTA and A.K.GUPTA \\ Department of Chemistry, Agra College, Agra, India. \\ *Corresponding author E-mail:jayagupta6250@gmail.com \\ http://dx.doi.org/10.13005/ojc/300474 \\ (Received: August 04, 2014; Accepted: September 26, 2014)

\begin{abstract}
A Phytochemical study was carried out on the leaves of Phyllanthus emblica. By using different chromatographic techniques the separation of the chemical compounds were done and structure of the compounds were elucidated by spectroscopic methods including nuclear magnetic resonance as well as mass spectrometry. Two compounds were isolated and identified; that are quercetin and $\beta$-sitosterol.
\end{abstract}

Key words: Euphorbiaceae, Phyllanthus emblica, quercetin, $\beta$-sitosterol, NMR.

\section{INTRODUCTION}

Phyllanthus emblica Linn., belongs to the family Euphorbiaceae, commonly known as Indian gooseberry and amla. It is distributed in tropical and subtropical regions of India. It is excellent source of vitamin C, easily assimilated by human body ${ }^{1}$.It is found all over India, along the sea-coast districts, in deciduous forest of Madhya Pradesh. It is helpful in lowering cholesterol level ${ }^{2}$ and protects from heart disease ${ }^{3-4}$, strengthens senses ${ }^{5}$, strengthens liver ${ }^{6}$. It is useful in diabetes ${ }^{7-8}$, gonorrhea, diuretic fevers, diarrhoea ${ }^{9}$, mouth ulcers, inflammations, hair growth, headache, colic, asthma, respiratory problems. It is used as antioxidant ${ }^{10}$, aphrodisiac, antifungal, antiviral, anticancer, antigenotoxic ${ }^{11}$, antimutagenic ${ }^{12}$, chelating agent.

\section{EXPERIMENTAL}

${ }^{1} \mathrm{H}$ NMR and ${ }^{13} \mathrm{C}$ NMR spectra were recorded on a Bruker Advance $400 \mathrm{MHz}$ spectrometer. The El-mass was recorded on Shimadju QP 2000 mass spectrometer. The leaves of Phyllanthus emblica was collected from Agra College, Agra. The leaves were air dried under shade for ten days. Then the leaves were powdered with the help of warming blender. The air dried powdered leaves $(500 \mathrm{gm})$ were subjected to successive hot extraction in a Soxhlet apparatus with solvents petroleum ether, ethyl alcohol and ethyl acetate. The average time period for extraction was 72 hours. The individual extracts were filtered twice and then concentrated by distillation on vaccum. The ethanolic extract ( $5 \mathrm{gm}$ ) was subjected to silica gel chromatography using isopropanol- 
formic acid-water (2:5:5), to give compound 1 quercetin.

A portion of the ethyl acetate extract (4 gm) was subjected to silica gel thin layer chromatography using n-hexane: acetone (80:20) solvent system to give compound 2 that is identified $\beta$-sitosterol. Quercetin and $\beta$-sitosterol were identified by comparison with data from previous NMR and mass spectra ${ }^{13-15}$.

\section{Quercetin}

Compound (1) Slightly yellow powder; m.p $316{ }^{\circ} \mathrm{C} ;{ }^{1} \mathrm{H}$ NMR $(400 \mathrm{MHz}, \mathrm{Me} \mathrm{OD}): \delta(\mathrm{ppm})=6.20$ $(1 \mathrm{H}, d, J=2.0 \mathrm{~Hz}, \mathrm{H}-6), 6.42(1 \mathrm{H}, d, J=2.0 \mathrm{~Hz}, \mathrm{H}-8)$, $6.90\left(1 \mathrm{H}, d, J=8.2 \mathrm{~Hz}, \mathrm{H}-5^{\prime}\right), 7.64(1 \mathrm{H}, d d, J=8.3$; $\left.2.1 \mathrm{~Hz}, \mathrm{H}-6^{\prime}\right), 7.76\left(1 \mathrm{H}, d, J=2.1 \mathrm{~Hz}, \mathrm{H}-2^{\prime}\right),{ }^{13} \mathrm{C}$ NMR $(100 \mathrm{MHz}, \mathrm{Me}$ OD): $\delta(\mathrm{ppm})=148.4(\mathrm{C}-2), 137.1$ ( C3), 177.4 ( C-4), 162.4(C-5), 99.2 ( C-6), 165.6 ( C-<smiles>O=c1c(O)c(-c2ccc(O)c(O)c2)oc2cc(O)cc(O)c12</smiles>

Fig. 1: Structure of Quercetin

\section{RESULTS AND DISCUSSION}

Aim of this study was to identify and characterize the bioactive principles from the leaves of Phyllanthus emblica. Compound 1 is a slightly yellow powder, m.p $316{ }^{\circ} \mathrm{C}$. The El-mass spectrum of 1 showed the molecular ion at $\mathrm{m} / \mathrm{z} 302\left[\mathrm{M}^{+}\right]$ corresponding to the formula $\mathrm{C}_{15} \mathrm{H}_{10} \mathrm{O}_{7}$ and in agreement with other spectroscopic data. The ${ }^{1} \mathrm{H}$ NMR showed that the proton of $\mathrm{H}-6$ and $\mathrm{H}-8$ appeared as a duplet at $\delta 6.20$ and 6.42 . The proton of $\mathrm{H}-5^{\prime}, \mathrm{H}-6^{\prime}$ and $\mathrm{H}-2^{\prime}$ appears at ä 6.90,7.64 and 7.76 respectively. ${ }^{13} \mathrm{CNMR}$ spectrum showed a carbonyl group at $\delta 177.4$.The carbon bonded to hydroxyl group appeared at $\delta 137.1,146.4,150.2$, 162.4 and165.6.
7), 94.8 ( C-8), 158.2 ( C-9), 104.6 ( C-10), 124.5 ( C-1'), 116.2 ( C-2', C-5'), 146.4 ( C-3'), 150.2 ( C4'), $121.7\left(\mathrm{C}-6^{\prime}\right)$.

\section{$\beta$-Sitosterol}

Compound (2) White powder, m.p $136^{\circ} \mathrm{C}$, ${ }^{1} \mathrm{HNMR} \quad\left(\mathrm{CDCl}_{3}, 400 \mathrm{MHz}\right): 5.38(1 \mathrm{H}, \mathrm{dd}, \mathrm{J}=5.2 \mathrm{~Hz}, \mathrm{H}-$ 6), $3.56(1 \mathrm{H}, \mathrm{tt}, \mathrm{J}=11.3 ; 5.3 \mathrm{~Hz}, \mathrm{H}-3), 2.34(1 \mathrm{H}, \mathrm{ddd}$, $\mathrm{J}=13.0 ; 5.0 ; 2.0 \mathrm{~Hz}, \mathrm{H}-4 \mathrm{a}) \quad 0.74,0.87,0.88,0.89,0$. 93,1.06 (each3H,s,MeX6). ${ }^{13} \mathrm{CNMR}\left(\mathrm{CDCl}_{3}\right.$, 100MHz): $837.1(\mathrm{C}-1), 31.5$ (C-2), 71.7(C-3),42.2(C4), 140.6(C-5), 121.6(C-6), 31.8 (C-7),31.7(C8), 50.2(C-9), 36.4(C-10), 21.2(C-11),39.7(C12), 42.2(C-13), 56.7(C-14), 24.2(C-15),28.1(C16), 56.0(C-17), 11.7(C-18), 19.3(C-19), 36.3 (C20), 18.9(C-21), 33.8(C-22), 26.1(C-23), 45.7(C-24), 29.2(C-25), 19.7(C-26), 19.1(C27), 23.0 (C-28), 12.1(C-29).

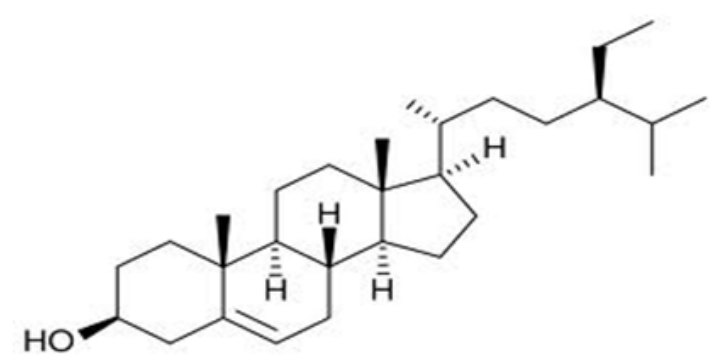

Fig. 2: Structure of $\beta$-Sitosterol

Compound 2 was isolated as white powder, m.p $136^{\circ} \mathrm{C}$. The El-mass spectrum of 2 showed the molecular ion at $\mathrm{m} / \mathrm{z} 414\left[\mathrm{M}^{+}\right]$ corresponding to the molecular formula $\mathrm{C}_{29} \mathrm{H}_{50} \mathrm{O}$ and in agreement with other spectroscopic data. The ${ }^{1} \mathrm{H}$ NMR spectrum showed a broad triplet at $\delta 5.38$ corresponding to $\mathrm{H}-6$ olefenic proton and multiple at $\delta 3.56$ corresponding to $\mathrm{H}-3$ alpha proton six tertiary methyl singlets. ${ }^{13} \mathrm{C}$ NMR of the compound showed 29 signals for steroid skeleton which was represented by six methyl groups. The carbon bonded to the hydroxyl group C-3 appeared at 71.7. The quercetin and $\beta$ - sitosterol has been earlier reported in various plants ${ }^{16-20}$. 


\section{CONCLUSION}

From the physical, chemical and spectral characteristics, compound 1and 2 were concluded as Quercetin (Fig.1) and $\beta$ - sitosterol (Fig.2). Quercetin is flavonoid, used in asthma, eczema, heyfever, and hives. It possess anti-inflammatory, anticancer, antiviral activity, inhibit inflammatory leukotriene production ${ }^{21}$. $\beta$ - sitosterol is phytosterol, used as antioxidant and an anti- diabetic agent. Human liver microsome studies reveals that $\beta$ sitosterol inhibits the cholesterol absorption, reduces the symptoms of benign prostatic hyperplasia ${ }^{22}$, anti-inflammatory ${ }^{23}$ and anti-pyretic activity. So medicinal properties of Phyllanthus emblica is due to the quercetin and $\beta$ - sitosterol, furthermore scientific evaluation are required to establish therapeutic efficacy.

\section{ACKNOWLEDGEMENTS}

We are very grateful to University Grants Commission, New Delhi, India for their financial assistance (Grant No.F.15-39/12 (SA-II)). We are also very thankful to Dr.M.K.Rawat, Principal Agra College, Agra for their support.

\section{REFERENCES}

1. Nisha,P.;Singhal.R.S., and Pandit, A.B.; Int JFood Sci Nutr. 2004,55(5),415-422.

2. Kim, H.J.; Yokozawat, Kimhy., Tohda, C.; Rao,T.P.; and Juneja,L.R.; J Nutr Sci Vitaminol. 2005,51,413-418

3. Yokozawa, T.; Kim, H.Y.; Kim, H.J.; Okubo, T.;C hu, D.C.; and Juneja, L.R.; Br. J. Nutr. 2007,97(6)1187-1195

4. Mathur,R.;Sharma,A.;Dixit,V.P.; and Verma,M.;J Ethnopharmacol,1996,50(2),6168

5. Reddy, V.D.; Padmavathi, P.V.; Kavitha, G.; Gopi, S.; and Varadacharyulu, N., J.Med Food 2011, 14(1-2),62-68

6. Tasduq,S.A;Kaisar,P.; and Gupta, D.K.; Phytoether Res. 2005,19(3),193-197

7. Nampoothiri,S.V.;Prathapan, A.; Cherian, O.C.; Raghu, K.G.;Venugopalan,U.V.; and Sundaresan,A.;Food ChemToxicol, 2011,49(1),125-131

8. Babu,P.S.;Stainley,Mainzen,; and Prince, P.,J. Pharm.Pharmacol,2004,56,(11),1435-1442

9. Mehmood,M.H.;Siddiqi,H.S.; and Gilani,A.H.; J.Ethnopharmacol,2011,133(2),856-865

10. Naik,G.H.; and Priyadarsini,K.I.;Phytoether Res.2005,19(7),582-586

11. Banu,S.M.;Selevendiran,K.;Singh,J.P.; and Sakthisekaran,D.; Hum. Exp. Toxicol, 2004, 23,527-531
12. Madhavi, D.; Rudrama,Devi.K.; Desava, Rao. K. and Reddy, P.P.; J. Envi. Biol. 2007,28,115117

13. Praveen, S.; Kader, Md.A.; Muhit, Md.A; Haque, Md.E.; and Mosaddik, Md.A.; JAPS,2011 1(9) 47-50

14. Karan,S.K.;Mishra,S.K.;Pal,D.K.; and Mandal,A.;J.Med.Plant Res.,2012,6(7),12191223

15. Trivedi, P.C.; and Chaudhary,N.; JPR, 2011, 4(11) ,4252-4253

16. Rahman,S.M.M.;Mukta,Z.A.; and Hossain,M.A.; As J Food Ag-Ind,2009, 2(1),39-43

17. Akhtar,P.; Ali,M.; Sharma, M.P.;Farooqi,H.; and Khan, H.N.; J.Phytol, 2010,2(3), 89-100

18. Khanam,S.; and Sultana,R.; IJSPR 2012,3(4), 1057-1060

19. Sarin, R., and Bansal,N.; IJRAP 2011, 2(3), 927-930

20. Subramaniam,S.S.; and Nair, A.G.R.; Phytyochem, 1972,11,439

21. Numata.Y.; and Tanaka,H.;Food Chemistry, 126, 2011,751-755

22. Wilt,T.J.;Macdonald,R.; and Ishani,A.; B.J.U Int., 1999,83(9),976

23. Loizou.S.,Lekakis,I.; Chrousos,G.P.; and Moutsatou,P.,Mol.Nut.Food Res., 2010, 54, 551. 